social adjustment to whatever degree of dysfunction they may exhibit will be facilitated by our own better understanding of the subtle and protean role of sexuality in the modern world.

\title{
PROSTIGMIN ASSESSMENT TEST OF FERTILITY IN SPINAL MAN
}

\author{
By Sir Ludwig Guttmann and Dr. J. J. Walsh \\ National Spinal Injuries Centre, Stoke Mandeville Hospital, \\ Aylesbury, England
}

SINCE Spellanzani's observations on the copulative posture of the spinal frog (I768) the patho-physiology of the sexual function in the spinal man both in animals and man has been a subject of clinical observations and physiological research (Tarchanow, I887; Thorburn, I888; Bernhardt, I888; Wagner \& Stolper, I898; Sherrington, 1906; Riddoch, I917; Foerster, 1936). However, it is only during the last 20 years or so that as a result of the greatly increased survival rate of patients with spinal cord injuries, comprehensive studies on potency and fertility in the spinal man have been undertaken. Investigators have employed various procedures to assess potency and fertility in these patients which can be divided into two main groups.

\section{A. Questionnaire and Personal Interview Techniques}

The investigators have, of course, to rely entirely on the statements of the individual by these techniques. Results obtained with these methods, were reported by Bors, in 1948 on 157 and 1963 on 529 patients, Talbot in 1949 on 208 and in 1955 on 408 patients, Zeitlin et al. in 1957 on 100 and Tsuji et al. in 196I on 655 patients. The latter authors stressed the difference between results obtained with the questionnaire technique and personal interview by finding a higher percentage of erections and ejaculations recorded by the personal interview technique. However, there is general agreement amongst all these authors that the percentage of erections 52-94 per cent. were infinitely higher than that of the ejaculations 3-I9.7 per cent. Intercourse possibility was 23-33 per cent., orgasm 6-I 4 per cent. and reproductive results were the lowest (up to 5 per cent.). Bors (1963) stated that while erection is more frequent with high lesions, ejaculation occurs more often in those with low lesions. This is not, as will be shown later, in accordance with our experience.

\section{B. Direct Examination of the Ejaculate obtained}

I. By Prostatic Massage. This technique was used by Horne, Paul and Munro (I948). These authors found that the amount of ejaculate by prostatic massage could be increased with prior electric rectal stimulation, a method which was previously employed by Dexter, Lerner and Kaplan (I940) and by Joel (I94I). However, Bors and co-workers were not impressed by the results obtained with this method in their own cases which was in accordance with Kuhn's findings (I950). 
2. By Testicular Biopsy. Bors and co-workers studied biopsy specimens from testes in 34 patients with spinal cord injuries. They found that in all but three cases the biopsy revealed tubular atrophy while there was no disturbance of Leydig cells. Furthermore, with two exceptions, they found a correlation between testicular biopsy findings and the level of the spinal cord lesion. Lesions at or below TII showed a lesser degree of testicular abnormalities. The authors also correlated the biopsy findings with the result of sweat tests using the Quinizarin method (Guttmann, 1937-47) and thus were able to study the relationship between testicular function and other components of the autonomic system. With four exceptions, a close relationship was found between testicular biopsy findings and the result of the sweat test. Lesser testicular changes were associated with normal sweating while major testicular abnormalities were associated with impaired sweating. However, the four exceptions showed that there may be dissociation between these two components of the autonomic system. The disdavantage of testicular biopsy is that, from obvious reasons, it cannot be considered as a routine method in these patients and moreover it cannot give any indication of the function of the genital organs as a whole nor does it give any indication of volume, sperm concentration, sperm motility and percentage of normal and abnormal forms.

3. By the Intrathecal Prostigmin Assessment Test. Since the discovery of a selectively stimulating action of prostigmin following intrathecal injection on the reproductive organs of the spinal man by one of us (L. G.) in 1947 this test was employed systematically ever since to assess the potentialities of erections and fertility in paraplegics and tetraplegics. It was found that as a rule a dosage of $0.3 \mathrm{mg}$. was sufficient to elicit erections and ejaculations in these patients who hitherto had been thought impotent and infertile. This exquisite stimulating effect of the intrathecal prostigmin on the genital organs is in amazing contrast to its depressant effect on the skeletal spastic muscules, the latter previously described in cerebral hemiplegic patients by Kremer and Wright (I94I). This depressant effect on spastic skeletal muscles was confirmed in spinal cord lesions as shown in Table I. This effect is in striking contrast to the stimulating effect of this drug on the muscular system following intramuscular injections as found in myasthenia gravis. Furthermore, the intrathecal prostigmin affects, in the great majority of patients, bladder retention for several hours.

Some of our results on the reproductive function on smaller numbers of patients have been previously described in detail (Guttmann, I953, I960). The present paper deals with a report on 134 patients with cord or cauda equina lesions at levels ranging from $\mathrm{C}_{5}$ to $\mathrm{S}_{4}$ in whom ${ }_{1} 80$ tests were carried out. One hundred and two patients had complete and 32 incomplete lesions, of whom ro4 showed spasticity of various degrees and 30 were flaccid. The average age of the patient was about 28 , the youngest being I 8 , the oldest 47 . All patients were in satisfactory general condition at the time of the test and free from infected sores, but the majority had some infection of the urinary tract.

\section{INDICATIONS}

The initial test was carried out to determine spermatic abnormalities, as it is well known that reduction of sperm concentration and reduced motility play an important role in male infertility. Both married and unmarried patients in the 
TABLE I

Effect of Intrathecal Prostigmine on Reflex Function

\begin{tabular}{|c|c|c|c|c|c|c|c|c|c|c|c|c|c|}
\hline \multirow{3}{*}{ Case } & \multirow{3}{*}{ Lesion } & \multicolumn{6}{|c|}{ Reflex function before injection } & \multicolumn{6}{|c|}{$\begin{array}{l}\text { Reflex function at time of ejaculation } \\
\text { or at height of effect on motor function }\end{array}$} \\
\hline & & \multicolumn{2}{|c|}{ K.J. } & \multicolumn{2}{|c|}{ A.J. } & \multicolumn{2}{|c|}{ P.R. } & \multicolumn{2}{|c|}{ K.J. } & \multicolumn{2}{|c|}{ A.J. } & \multicolumn{2}{|c|}{ P.R. } \\
\hline & & R. & L. & R. & L. & $\mathrm{R}$. & L. & $\mathrm{R}$. & L. & $\mathrm{R}$. & L. & R. & L. \\
\hline I & $\mathrm{C}_{7}$ Complete & - & \pm & ++ & ++ & $\downarrow$ & $\downarrow$ & - & - & - & + & & $\downarrow$ \\
\hline 2 & T5 Complete & +++ & $+\bar{t}+$ & +++ & +++ & $\uparrow$ & $\uparrow$ & - & - & ? & & $(\downarrow)$ & $(\downarrow)$ \\
\hline 3 & T6 Complete & ++ & ++ & +++ & \pm & $\downarrow$ & $\uparrow$ & - & - & $(+)$ & \pm & & $(\uparrow)$ \\
\hline 4 & T6/7 Complete & +++ & + & ++ & +++ & $\uparrow$ & $\uparrow$ & - & $(+)$ & - & $(\overline{+})$ & $(\downarrow)$ & $(\uparrow)$ \\
\hline 5 & T6/7 Complete & ++ & ++ & +++ & +++ & $\uparrow$ & $\uparrow$ & - & - & $((+))$ & $((+))$ & $(\downarrow)$ & $(\downarrow)$ \\
\hline 6 & T7 Complete & +++ & +++ & +++ & +++ & $\uparrow$ & $\uparrow$ & - & - & - & - & $(\uparrow)$ & $(\uparrow)$ \\
\hline 7 & T7 Complete & +++ & +++ & \pm & ++ & $\uparrow$ & $\uparrow$ & - & - & - & - & - & $(\downarrow)$ \\
\hline 8 & T7 Complete & +++ & +++ & 二 & - & - & - & $(+)$ & +++ & - & - & - & - \\
\hline 9 & T9 Complete & ++ & ++ & ++ & ++ & $\uparrow$ & $\uparrow$ & $(+)$ & $(+)$ & $(+)$ & $(+)$ & & $\downarrow$ \\
\hline IO & Tio Incomplete & +++ & +++ & +++ & +++ & $\uparrow$ & $\uparrow$ & + & - & + & + & $(\downarrow)$ & $(\downarrow)$ \\
\hline I I & Tro Complete & + & - & ++ & ++ & $\uparrow$ & $\downarrow$ & + & - & ++ & $(+)$ & $\uparrow$ & - \\
\hline 12 & Tio Complete & +++ & +++ & +++ & +++ & $\uparrow$ & $\uparrow$ & - & - & - & - & - & - \\
\hline 13 & TII/I2 Complete & - & - & +++ & + & $(\downarrow)$ & $\uparrow$ & + & - & $(+)$ & - & $((\downarrow))$ & - \\
\hline I4 & LI/L2 Complete & + & + & - & - & - & - & - & - & - & - & - & - \\
\hline 15 & $\begin{array}{l}\text { Li/L3 Complete } \\
\text { (Spastic) }\end{array}$ & - & - & +++ & +++ & $\uparrow$ & $\uparrow$ & - & - & - & - & - & - \\
\hline I6 & $\begin{array}{l}\text { L2 Complete } \\
\text { (Spastic) }\end{array}$ & ++ & + & +++ & +++ & $\uparrow$ & $\uparrow$ & - & - & - & - & - & - \\
\hline 17 & L5 Complete & + & - & - & - & - & $\uparrow$ & - & - & - & - & - & - \\
\hline I 8 & SI Incomplete & - & - & - & - & - & - & - & - & - & - & - & - \\
\hline I9 & S2 Incomplete & + & + & + & - & $\downarrow$ & $\downarrow$ & - & - & - & - & - & - \\
\hline
\end{tabular}


great majority are naturally very interested in their chances of reproductive activity. This information was found to be sometimes particularly important in the cases of the Catholic faith or those who were engaged to Catholic girls.

Repeated tests were carried out, (I) to check the motility and concentration of sperms and their cytology, (2) to repeat the test with a higher dosage when the first test revealed a negative result (in a few of the patients the dosage had to be increased to $0.5,0.7$ and even I mg.), (3) to check motility concentration and differential cytology following hormone treatment, (4) for the purpose of artificial insemination.

\section{METHODS AND DOSAGE}

Because of certain undesirable side-effects, especially vomiting, the patient has to refrain from solid food for some hours before the test, and for three hours before injection the patient should not take anything by mouth. Before the test a full neurological examination of the lower limbs is carried out and full assessment of reflexes and muscle tone has to be made. This is of special importance in more distal cord lesions as there are often mixed forms of spasticity and hypo- or areflexia in certain parts of the lower limbs. This is particularly apparent in transverse lesions below Tro/II, where the injury may also affect the conus and epiconus, or in higher transverse lesions which are combined with longitudinal damage.

Procedure. The patient is prepared in the usual way for a lumbar puncture and the test is carried out in a separate room. The drug used was neostigmine methyl sulphate (prostigmin-Roche), made up in I-cc. ampules each containing $0.5 \mathrm{mg}$. and a clearly marked 2-cc. syringe is essential for the accurate amount of prostigmin injected.

After lumbar puncture (carried out in lateral position) the Quechenstedt test is carried out to ascertain the presence of absence of a suparachnoid block as this has some bearing on the dosage. If there is no or only a partial block, $0.3 \mathrm{mg}$. prostigmin is injected after first withdrawing I-2 cc. C.S.F. into the syringe to mix with the prostigmin. In high thoracic and cervical injuries it is safer to start with $0.25 \mathrm{mg}$. because of the rise in blood pressure in these high lesions during ejaculations as a result of powerful contractions of the seminal vesicles and other ejaculatory organs, which may set up the same autonomic hyperreflexia as described previously by the forceful contraction of bladder and other internal organs (Guttmann \& Whitteridge, I947; Guttmann, 1954, 1969). If there was a complete block, 0.3 to $0.5 \mathrm{mg}$. was injected. In some cases where the initial test was negative and especially if the neurological examination indicated little or no effect on muscle tone and reflexes, the test was repeated using larger doses of prostigmin provided there had been no untoward side-effects during the original injection. Up to I $5 \mathrm{mg}$. prostigmin has been given in one exceptional case of conus-cauda equina lesion. After injection the needle is withdrawn, a dressing applied and the patient turned on his back with a pillow under his head. A glass container of a suitable size with a wide screw-cap is given to the patient with instructions to observe any erections and obtain any semen ejaculated. The examination of reflexes and muscle tone in the lower limbs is carried out repeatedly after the injection and recorded every $\frac{1}{2}-\mathrm{I}$ hour as this gives a good indication of the effect of prostigmin in each individual case. In distal lesions with areflexia this information is, of course, not obtainable. It is also important to measure pulse and blood pressure regularly during the test, 
especially in high thoracic and cervical lesions because of the possibility of exaggerated autonomic hyperreflexia due to seminal contraction during ejaculation. Moreover, in high thoracic and in particular cervical lesions a cystometrogram some time prior to the prostigmin test may give a clue about the degree of irritability of the autonomic system.

\section{RESULTS}

The depressant effect on reflex function of the skeletal muscles started as a rule between 15 and 20 minutes after intrathecal injection, but there was as a rule a considerable delay-one to three hours-before the onset of erections and ejaculations which usually occurred at the height of the reflex depression. Once an

TABLE II

Prostigmine Test

\begin{tabular}{|c|c|c|c|c|c|c|}
\hline & & & & & Positive & Negative \\
\hline \multirow{2}{*}{$\begin{array}{l}\text { Spastic } \\
(77 \cdot 6 \%)\end{array}$} & IO4 & Complete & 75 & $(72 \cdot 1 \%)$ & $44 \quad(59.7 \%)$ & $31 \quad(40 \cdot 3 \%)$ \\
\hline & & Incomplete & 29 & $(27.9 \%)$ & $23(79 \cdot 3 \%)$ & $6 \quad(20 \cdot 7 \%)$ \\
\hline \multirow{2}{*}{$\begin{array}{l}\text { Flaccid } \\
(22 \cdot 4 \%)\end{array}$} & 30 & Complete & 27 & $(90 \%)$ & $9 \quad(33.3 \%)$ & I8 $(66 \cdot 7 \%)$ \\
\hline & & Incomplete & 3 & $(10 \%)$ & $2(66.7 \%)$ & I $\quad(33.3 \%)$ \\
\hline Total & I34 & & I34 & & $78 \quad(58 \cdot 2 \%)$ & $56 \quad(4 \mathrm{I} \cdot 9 \%)$ \\
\hline
\end{tabular}

erection had started it continued in most of the cases for a considerable time, either intermittently or continuously and sometimes it persisted for hours even after emissions occurred. In two low thoracic lesions (Tro and TI2) and one conus lesion, ejaculations occurred without erections. The number of ejaculations varied considerably from patient to patient and also in different tests in the same patient. Only the minority of patients produced a single emission and as many as seven or more were observed in some patients within a period of two hours. Table II shows number and percentage of positive ejaculations results in our I34 patients. 59.7 per cent. of the 70 complete and 75.4 per cent. of the incomplete spastic lesions showed positive results, while in 66.7 per cent. of the complete flaccid lesions no ejaculations occurred. As will be seen in Table III the majority of negative results occurred in lesions at levels between Tro and L4.

The volume of the ejaculated seminal fluid varied considerably from patient to patient and also in different tests on the same patient. In those cases who had several ejaculations the volume of each emission became progressively less. However, sometimes the second or third emission was found to be larger than the first. This may be accounted for by the fact that in these cases there had been no ejaculation for very long periods before the tests and it would appear that in some of them accumulated stimuli were necessary to set the whole mechanism of ejaculation into action.

No relationship was found between volume and sperm concentration in the 
TABLE III

Prostigmine Test

\begin{tabular}{|c|c|c|c|c|c|c|}
\hline & & & & & Positive & Negative \\
\hline \multirow[t]{2}{*}{$\begin{array}{l}\text { Cervical } \\
(7 \cdot 46 \%)\end{array}$} & IO & Complete & $\begin{array}{l}\text { Spastic } \\
\text { Flaccid }\end{array}$ & $\begin{array}{l}3 \\
I\end{array}$ & $\begin{array}{r}\mathrm{I} \\
\ldots\end{array}$ & $\begin{array}{l}2 \\
I^{*}\end{array}$ \\
\hline & & Incomplete & $\begin{array}{l}\text { Spastic } \\
\text { Flaccid }\end{array}$ & $\begin{array}{c}6 \\
\ldots\end{array}$ & $\begin{array}{c}6 \\
\cdots\end{array}$ & $\begin{array}{l}\ldots \\
\cdots\end{array}$ \\
\hline \multirow[t]{2}{*}{$\begin{array}{l}\text { TI-T6 } \\
(22 \cdot 38 \%)\end{array}$} & 30 & Complete & $\begin{array}{l}\text { Spastic } \\
\text { Flaccid }\end{array}$ & $\begin{array}{r}25 \\
2\end{array}$ & $\begin{array}{r}20 \\
I\end{array}$ & $\begin{array}{l}5 \\
I\end{array}$ \\
\hline & & Incomplete & $\begin{array}{l}\text { Spastic } \\
\text { Flaccid }\end{array}$ & $\begin{array}{r}3 \\
\ldots\end{array}$ & $\begin{array}{c}3 \\
\ldots\end{array}$ & $\begin{array}{l}\ldots \\
\cdots\end{array}$ \\
\hline \multirow[t]{2}{*}{$\begin{array}{l}\mathrm{T}_{7-\mathrm{T}_{9}} \\
(22 \cdot 38 \%)\end{array}$} & 30 & Complete & $\begin{array}{l}\text { Spastic } \\
\text { Flaccid }\end{array}$ & $\begin{array}{r}19 \\
\text { I }\end{array}$ & $\begin{array}{l}\text { I4 } \\
\ldots\end{array}$ & $\begin{array}{l}5 \\
\mathrm{I}\end{array}$ \\
\hline & & Incomplete & $\begin{array}{l}\text { Spastic } \\
\text { Flaccid } \\
\quad \text { (Polio) }\end{array}$ & $\begin{array}{l}9 \\
\text { I }\end{array}$ & $\begin{array}{l}5 \\
\text { I }\end{array}$ & $\begin{array}{c}4 \\
\cdots\end{array}$ \\
\hline \multirow[t]{2}{*}{$\begin{array}{c}\text { Tro-Tr2 } \\
(31 \cdot 34 \%)\end{array}$} & 42 & Complete & $\begin{array}{l}\text { Spastic } \\
\text { Flaccid }\end{array}$ & $\begin{array}{l}\text { I9 } \\
\text { I2 }\end{array}$ & $\begin{array}{l}7 \\
3\end{array}$ & $\begin{array}{r}12 \\
9\end{array}$ \\
\hline & & Incomplete & $\begin{array}{l}\text { Spastic } \\
\text { Flaccid }\end{array}$ & $\begin{array}{r}\text { IO } \\
\text { I }\end{array}$ & $\begin{array}{l}8 \\
\mathrm{I}\end{array}$ & $\begin{array}{l}2 \\
\cdots\end{array}$ \\
\hline \multirow[t]{2}{*}{$\begin{array}{l}\mathrm{LI}_{-\mathrm{L} 4} \\
\quad(\mathrm{II} \cdot 97 \%)\end{array}$} & 16 & Complete & $\begin{array}{l}\text { Spastic } \\
\text { Flaccid }\end{array}$ & $\begin{array}{l}8 \\
8\end{array}$ & $\begin{array}{l}2 \\
3\end{array}$ & $\begin{array}{l}6 \\
5\end{array}$ \\
\hline & & Incomplete & $\begin{array}{l}\text { Spastic } \\
\text { Flaccid }\end{array}$ & $\begin{array}{l}\cdots \\
\cdots\end{array}$ & $\begin{array}{l}\cdots \\
\cdots\end{array}$ & $\begin{array}{l}\cdots \\
\cdots\end{array}$ \\
\hline \multirow[t]{2}{*}{$\begin{array}{l}\mathrm{L}_{5}-\mathrm{S}_{4} \\
(4 \cdot 47 \%)\end{array}$} & 6 & Complete & $\begin{array}{l}\text { Spastic } \\
\text { Flaccid }\end{array}$ & $\begin{array}{l}\text { I } \\
3\end{array}$ & $\begin{array}{r}\cdots \\
2\end{array}$ & $\begin{array}{l}\text { I } \\
\text { I }\end{array}$ \\
\hline & & Incomplete & $\begin{array}{l}\text { Spastic } \\
\text { Flaccid }\end{array}$ & $\begin{array}{l}\text { I } \\
\text { I }\end{array}$ & $\begin{array}{r}\text { I } \\
\cdots \\
\end{array}$ & 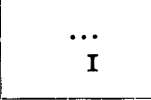 \\
\hline Total & I34 & & & 134 & 78 & 56 \\
\hline
\end{tabular}

* Alcohol Block

various subjects or in repeated tests on the same subject. Considerable variations were found and the ejaculate may be just prostatic fluid with complete aspermia. Conversely, a small volume of seminal fluid may contain a much higher sperm concentration than a large volume. 
TABLE IV

\begin{tabular}{|c|c|c|c|c|c|c|c|c|c|c|c|c|}
\hline \multirow{2}{*}{ Name } & \multirow{2}{*}{ Age } & \multirow{2}{*}{$\begin{array}{l}\text { Date of } \\
\text { test }\end{array}$} & \multicolumn{2}{|c|}{ Level of lesion } & \multirow{2}{*}{ Spastic } & \multirow{2}{*}{ Flaccid } & \multirow{2}{*}{$\begin{array}{c}\text { Dose } \\
\text { prostig- } \\
\text { mine } \\
\text { mg. }\end{array}$} & \multirow{2}{*}{$\begin{array}{l}\text { Result } \\
\text { emission }\end{array}$} & \multirow{2}{*}{$\begin{array}{l}\text { Volume } \\
\text { cc. }\end{array}$} & \multirow{2}{*}{$\begin{array}{l}\text { Count } \\
\text { mill. }\end{array}$} & \multirow{2}{*}{$\begin{array}{l}\text { Motility } \\
\text { per cent }\end{array}$} & \multirow{2}{*}{$\begin{array}{l}\text { Differential } \\
\text { count }\end{array}$} \\
\hline & & & Comp. & Incomp. & & & & & & & & \\
\hline Sturg. & 32 & 9. I I. 48 & - & TI2 & + & - & 0.4 & $\begin{array}{l}\text { I-(Urine) } \\
2-\text { (Urine) } \\
3-\text { (Urine) } \\
4+ \\
5+ \\
6+ \\
7+\end{array}$ & $\begin{array}{l}- \\
- \\
- \\
I \cdot 0 \\
I \cdot I \\
I \cdot 2 \\
0 \cdot 7\end{array}$ & $\begin{array}{l}- \\
- \\
- \\
87 \\
51 \\
58 \\
41\end{array}$ & $\begin{array}{l}- \\
- \\
- \\
44 \\
42 \\
37 \\
33\end{array}$ & $\begin{array}{l}73 \% \text { abnormal } \\
14 \% \text { immature }\end{array}$ \\
\hline Fro. & 29 & I0.9.48 & $S_{I}$ & - & - & + & 0.5 & $\begin{array}{ll}I & + \\
& \\
2 & + \\
3 & + \\
4 & + \\
5 & + \\
6 & + \\
7 & +\end{array}$ & $\begin{array}{l}I \cdot 0 \\
I \cdot I \\
0 \cdot 9 \\
0 \cdot 5 \\
0 \cdot 5 \\
0 \cdot 3 \\
0 \cdot 3\end{array}$ & $\begin{array}{l}4 \cdot 5 \\
3 \cdot 1 \\
2 \\
2 \cdot 3 \\
0 \cdot 95 \\
0 \cdot 6 \\
0 \cdot 56\end{array}$ & $\begin{array}{r}23 \\
20 \\
17 \\
18 \\
11 \\
9 \\
5\end{array}$ & $\begin{array}{c}\text { Squamous cells }+ \\
\text { Testicular cells }+ \\
\text { Testicular cells }+ \\
\text { Testicular cells }+ \\
\text { Testicular cells }+ \\
\text { Debris } \\
\text { Debris } \\
\text { Debris }\end{array}$ \\
\hline Harv. & 27 & 2.2 .48 & $\mathrm{C}_{7} / \mathrm{T}_{\mathrm{I}}$ & - & + & - & 0.3 & $\begin{array}{cc}1 & + \\
2 / 3 & + \\
4 / 5 & + \\
6 & +\end{array}$ & $\begin{array}{l}I \\
2 \\
0.5 \\
0.5\end{array}$ & $\begin{array}{l}73 \\
57 \\
23 \\
15\end{array}$ & $\begin{array}{r}2 \\
4 \\
20 \\
20\end{array}$ & $\begin{array}{l}\text { Pus cells } \\
\text { Pus cells \& R.B.C. } \\
\text { Pus cells \& R.B.C. } \\
\text { Pus cells \& R.B.C. }\end{array}$ \\
\hline Morg. & 37 & 8.1 .48 & - & C6 & + & - & 0.3 & $\begin{array}{ll}\mathbf{I} & + \\
2 & +\end{array}$ & $\begin{array}{l}I \cdot 5 \\
7 \cdot 7\end{array}$ & $\begin{array}{l}45 \\
46\end{array}$ & $\begin{array}{l}60 \\
50\end{array}$ & $\overline{-}$ \\
\hline Craw. & 23 & I2.10.56 & $\mathrm{T}_{7}$ & - & + & - & 0.4 & $\begin{array}{ll}\mathbf{I} & + \\
2 & + \\
3 & + \\
4 & + \\
5 & +\end{array}$ & $\begin{aligned} & 5.0 \\
& 2.5 \\
& I .5 \\
& \\
&< \\
&<\mathrm{I}\end{aligned}$ & $\begin{array}{c}100 \\
100 \\
50 \\
25 \\
\text { nil }\end{array}$ & $\begin{array}{l}10 \% \\
(5 \%) \\
\text { weak }\end{array}$ & - \\
\hline
\end{tabular}


The percentage of viable motile sperms was, as a rule, well below normal, especially in complete lesions, but in a small number of patients there were 50 per cent. and more of viable sperms. Table IV demonstrates the results obtained in five patients complete and incomplete, of various level who during the test had more than one emission. It is known from fertility tests in normal subjects that, although a high motility of sperms is an essential property of fertile spermatozoa, the ratio of motility provides only a rough index to the viability of the sperm population and its suitability for fertilising the ovum.

\section{TABLE V}

Comparative Microscopic Results of Seminal Fluid in Two Prostigmine Tests Cauda Equina Lesion (incomplete) below L5

\begin{tabular}{|c|c|c|c|c|c|c|}
\hline \multirow{2}{*}{ Specimen } & \multicolumn{2}{|c|}{ Volume } & \multicolumn{2}{|c|}{$\begin{array}{c}\text { Count } \\
\text { (millions, Icc) }\end{array}$} & \multicolumn{2}{|c|}{ Motility } \\
\hline & $\begin{array}{l}\text { I3.2. } 48 \\
\text { c.c. }\end{array}$ & $\begin{array}{l}\text { 5.10. } 48 \\
\text { c.c. }\end{array}$ & I3.2.48 & 5.10 .48 & $\begin{array}{c}\text { I3.2.48 } \\
\text { per cent. }\end{array}$ & $\begin{array}{c}\text { 5.10.48 } \\
\text { per cent. }\end{array}$ \\
\hline I & 0.5 & $I \cdot O$ & I I & 50 & 5 & 70 \\
\hline 2 & 0.5 & $I \cdot O$ & 12 & 49 & IO & 70 \\
\hline 3 & 0.5 & $5 \cdot 0$ & I I I & II 6 & 40 & 50 \\
\hline 4 & 4.5 & $\mathrm{I} \cdot \mathrm{O}$ & 90 & 57 & 40 & 50 \\
\hline 5 & $I \cdot 0$ & $I \cdot O$ & 122 & 47 & 30 & 40 \\
\hline 6 & 0.5 & $2 \cdot 0$ & 142 & 3.6 & 30 & 20 \\
\hline
\end{tabular}

\section{Differential count: 13.2 .48}

Specimen I : $50 \%$ abnormal forms (some tailless, some with two heads) Specimen $6: 40 \%$ abnormal forms (some tailless, some with two heads)

Differential count: 5.10 .48

Specimen $3:$ Head abnormalities $=49 \%$

Middlepiece and Tail abnormalities $=26 \%$

Total abnormalities $=55 \%$

Specimen $4:$ Head abnormalities $=36 \%$

$$
\begin{array}{r}
\text { Middlepiece and Tail abnormalities }=29 \% \\
\text { Total abnormalities }=65 \%
\end{array}
$$

Considerable variations were also found on detailed cytological examination in the percentage of normal and abnormal forms of sperms and other cells. The following case (case I7, Table I) may serve as an example of detailed cytological examination, the more so as a comparison is possible between two tests carried out in this patient.

This patient was wounded in June 1944, and sustained incomplete Cauda Equina lesion below L5. He had cordotomy in October 1944, because of pain in right leg. There was recurrence of pain after three weeks although less severe. He had erections and nocturnal emissions three months after injury, but lost emissions after cordotomy. $\mathrm{He}$ has spontaneous erections and is able to walk. First intrathecal prostigmin test I7.2.48, $0.3 \mathrm{mg}$. Second test 5.I I.48, $0.3 \mathrm{mg}$. He had six emissions on each occasion.

Table $\mathrm{V}$ shows the comparative microscopic results of seminal fluid in the 
two tests. Table VI shows six patients with negative results in repeated tests in spite of increased dosage. It may be noted, however, that in particular one single negative result does not necessarily signify permanent infertility as improvement of reproductive function is possible. Actually the prostigmin test may act as an induced stimulus on the function of the reproductive organs. Three of our patients with negative results became fathers later, one, an incomplete lesion below $\mathrm{T}_{7}$, even of twins. Although from obvious reasons some scepticism may be justified in such cases, the possibility of such achievement cannot be ruled out.

It has already been mentioned that one of the reasons for the prostigmin test is to use the seminal fluid obtained for artificial insemination at the patient's request who failed to get ejaculations during intercourse. The first four cases have been reported previously (Guttmann, I96I). They were all unsuccessful. However, the cause may not have been in all four cases necessarily with the paraplegic male. In one of the cases examination of the wife revealed an uterus bicornis and in another the wife was suffering from inflammation of the cervix. In Io more cases artificial insemination was since carried out by one of us (J. J. W.). In two cases the wives conceived but in one abortion took place after three months and in the other after five months. No information is available about the gynaecological condition of the wives of these patients. Table VII gives information about the number of artificial inseminations carried out in five cases and the findings of the seminal fluid. However, that this method can be used successfully has been shown by Dr. R. Spira (1956), whose paraplegic patient, a complete 7 th thoracic lesion, fathered a child after three unsuccessful attempts by assisted insemination with the help of the intrathecal prostigmin test. This case also shows that improvement of fertility is possible in the paraplegic. Spira's patient was treated with Testosterone, $25 \mathrm{mg}$. daily for I4 days and Gonadotrophin Iooo units daily for four weeks. We also have given hormonal treatment combined with vitamin E $20 \mathrm{mg}$. three times daily and in certain cases with weak erections with Potensan (Medo) 2-3 pellets, two to three times daily. Although we have seen definite improvement of fertility our results do not allow definite conclusions.

Side-effects on Autonomic Mechanisms. This paper should not be completed without mentioning some undesirable side-effects of prostigmin on the cardio-vascular system and other components of autonomic mechanisms. Headaches, sweating and vomiting may occur regardless of the lesion, and if vomiting becomes more marked it may counteract the stimulating effect on the reproductive organs. It can be controlled by I/roo Atropine. Only in three cases it was thought wise to give an intravenous drip of saline to prevent dehydration. It has already been mentioned that in cord lesions above $\mathrm{T}_{5}$ and in particular cervical lesions, violent contractions of the ejaculatory organs can set up exaggerated autonomic hyperreflexia with considerable rise of systolic and diastolic blood pressure and in one case with complete tetraplegia below $\mathrm{C}_{7}$ the initial blood pressure of 90/70 rose during the ejaculatory stage of the test to $230 / 150$. Immediate application of Pentolonium (Ansolysen) intravenously reduced immediately the paroxysmal hypertension. It may be noted that in this case a previous cystometrogram revealed a very irritable discoordinated automatic bladder and an infusion of only $50 \mathrm{cc}$. of fluid into the bladder elicited repeated and most powerful detrusor contractions. Therefore, it may be useful to carry out a cystometrogram prior to the prostigmin test in high cord lesions to ascertain the degree of irritability of autonomic 
TABLE VI

\begin{tabular}{|c|c|c|c|c|c|c|c|c|}
\hline \multirow{2}{*}{ Name } & \multirow{2}{*}{ Age } & \multirow{2}{*}{ Date of test } & \multicolumn{2}{|c|}{ Level of lesion } & \multirow{2}{*}{ Spastic } & \multirow{2}{*}{ Flaccid } & \multirow{2}{*}{$\begin{array}{l}\text { Dose } \\
\text { prostigmine } \\
(\mathrm{mg} .)\end{array}$} & \multirow{2}{*}{ Result } \\
\hline & & & Comp. & Incomp. & & & & \\
\hline Vid. & 21 & $\begin{array}{l}22.5 .63 \\
13.6 .63\end{array}$ & T6 & - & - & + & $\begin{array}{l}0.4 \\
0.5\end{array}$ & - \\
\hline Att. & 43 & $\begin{array}{r}3.10 .66 \\
31.10 .66 \\
29.11 .66\end{array}$ & Tio & - & + & - & $\begin{array}{l}0.25 \\
0.37 \\
0.75\end{array}$ & $\begin{array}{l}- \\
- \\
-\end{array}$ \\
\hline Crock. & 22 & $\begin{array}{l}27.7 .64 \\
21.9 .64\end{array}$ & - & Tro & + & - & $\begin{array}{l}0.3 \\
0.5\end{array}$ & $\overline{-}$ \\
\hline All. & 30 & $\begin{array}{r}5.4 .62 \\
2.5 .62 \\
20.11 .62\end{array}$ & - & TII & \pm & - & $\begin{array}{l}0.3 \\
0.5 \\
0.75\end{array}$ & $\begin{array}{l}- \\
- \\
-\end{array}$ \\
\hline Win. & 25 & $\begin{array}{r}8.9 .60 \\
6.10 .60 \\
2.11 .60\end{array}$ & TI2 & - & + & - & $\begin{array}{l}0.3 \\
0.5 \\
0.75\end{array}$ & $\begin{array}{l}- \\
- \\
-\end{array}$ \\
\hline Holl. & 30 & $\begin{array}{l}29.7 .63 \\
24.1 .64\end{array}$ & $\mathrm{Lr} / 3$ & - & \pm & - & $\begin{array}{l}0.3 \\
0.6\end{array}$ & - \\
\hline
\end{tabular}


TABLE VII

\begin{tabular}{|c|c|c|c|c|c|c|c|c|c|c|c|c|c|}
\hline \multirow{2}{*}{ Name } & \multirow{2}{*}{ Age } & \multirow{2}{*}{$\begin{array}{c}\text { Date of } \\
\text { prostigmin }\end{array}$} & \multicolumn{4}{|c|}{ Level } & \multirow{2}{*}{ Dose } & \multirow{2}{*}{$\begin{array}{l}\text { Result } \\
\text { No. of } \\
\text { emissions }\end{array}$} & \multirow{2}{*}{$\begin{array}{l}\text { Total } \\
\text { sperm }\end{array}$} & \multirow{2}{*}{$\begin{array}{l}\text { Motility } \\
\text { per cent }\end{array}$} & \multirow{2}{*}{$\begin{array}{l}\text { Pus } \\
\text { cells }\end{array}$} & \multirow{2}{*}{$\begin{array}{l}\text { Insemi- } \\
\text { nation }\end{array}$} & \multirow{2}{*}{$\begin{array}{l}\text { Result } \\
\text { insem. }\end{array}$} \\
\hline & & & Comp. & Incomp. & Spastic & Flaccid & & & & & & & \\
\hline Den. & 28 & $\begin{array}{r}10.4 .69 \\
30.6 .69\end{array}$ & & C6 & $\begin{array}{l}\text { Yes } \\
\text { Yes }\end{array}$ & & $\begin{array}{l}0.25 \\
0.25\end{array}$ & +3 & $\begin{array}{c}\text { I00 m. } \\
60 \mathrm{~m} . \\
25 \mathrm{~m} . \\
\\
\text { I75 m. } \\
\text { I00 m. } \\
\text { I00 m. }\end{array}$ & $\begin{array}{l}<5 \\
16 \\
20 \\
\\
15(\text { IO sl) } \\
\text { I5(IO sl) } \\
\text { I5(5 sl) }\end{array}$ & $\begin{array}{c}\text { RBC } \\
+++ \\
\text { no signi- } \\
\text { ficant } \\
\text { growth }\end{array}$ & + & - \\
\hline Cor. & 30 & $\begin{array}{r}12.4 .65 \\
11.6 .65 \\
12.10 .65 \\
\\
\\
11.7 .66 \\
18.10 .66 \\
24.2 .67 \\
19.6 .67\end{array}$ & $\begin{array}{l}\mathrm{T}_{5} \\
\mathrm{~T}_{5} \\
\mathrm{~T}_{5} \\
\\
\mathrm{~T} 5 \\
\mathrm{~T}_{5} \\
\mathrm{~T} 5 \\
\mathrm{~T} 5\end{array}$ & & $\begin{array}{l}\text { Yes } \\
\text { Yes } \\
\text { Yes } \\
\\
\text { Yes } \\
\text { Yes } \\
\text { Yes } \\
\text { Yes }\end{array}$ & & \begin{tabular}{l|}
0.3 \\
0.3 \\
0.4 \\
\\
\\
0.45 \\
0.4 \\
0.4 \\
0.4
\end{tabular} & $\begin{array}{l}+2 \\
+2 \\
+2 \\
\\
+2 \\
+2 \\
+1 \\
+2\end{array}$ & $\begin{array}{c}45 \mathrm{~m} . \\
50 \mathrm{~m} . \\
\text { not } \\
\text { reported } \\
\\
\text { roo m. } \\
70 \mathrm{~m} . \\
? \\
?\end{array}$ & $\begin{array}{c}6 \\
5 \\
<5 \\
\text { sl. active } \\
\\
\text { 10 } \\
7 \\
? \\
?\end{array}$ & +++ & $\begin{array}{c}+ \\
+ \\
+ \\
\\
\\
+ \\
+ \\
+ \\
+ \text { with } \\
\text { Dutch } \\
\text { cap }\end{array}$ & $\begin{array}{l}- \\
\text { ?3/12 } \\
\text { abortion } \\
\text { correspond- } \\
\text { ence } \\
- \\
- \\
-\end{array}$ \\
\hline Sym. & 28 & $\begin{array}{r}\text { I8. I I.66 } \\
\text { II.2.67 } \\
\text { I9.9.67 }\end{array}$ & & $\begin{array}{l}\text { T6 } \\
\text { T6 } \\
\text { T6 }\end{array}$ & $\begin{array}{l}\text { Yes } \\
\text { Yes } \\
\text { Yes }\end{array}$ & & $\begin{array}{l}0.25 \\
0.25 \\
0.25\end{array}$ & $\begin{array}{l}+3 \\
+5 \\
+4 / 5\end{array}$ & $\begin{array}{l}50 \mathrm{~m} . \\
45 \mathrm{~m} . \\
40 \mathrm{~m} .\end{array}$ & $\begin{array}{l}10 \\
40 \\
20\end{array}$ & $\begin{array}{c}+++ \\
+++ \\
+\end{array}$ & $\begin{array}{l}+ \\
+ \\
+\end{array}$ & $\begin{array}{l}- \\
- \\
-\end{array}$ \\
\hline Elm. & 36 & $\begin{array}{r}\text { I9.5.66 } \\
7.11 .67 \\
24.10 .68\end{array}$ & $\begin{array}{l}\mathrm{T}_{7} \\
\mathrm{~T}_{7} \\
\mathrm{~T}_{7}\end{array}$ & & $\begin{array}{l}\text { Yes } \\
\text { Yes } \\
\text { Yes }\end{array}$ & & $\begin{array}{l}0.3 \\
0.4 \\
0.4\end{array}$ & $\begin{array}{l}- \\
+1 \\
+3\end{array}$ & $\begin{array}{c}\text { some } \\
\text { motile } \\
65 \mathrm{~m} .\end{array}$ & $\begin{array}{l}\text { (I0) sl. } \\
\text { I }\end{array}$ & $\begin{array}{c}- \\
\text { sterile }\end{array}$ & $\begin{array}{l}+ \\
+\end{array}$ & - \\
\hline Reev. & $\begin{array}{l}29 \\
38\end{array}$ & $\begin{array}{r}3.3 .56 \\
9.8 .65 \\
\text { I0.1.66 } \\
2.5 .66\end{array}$ & $\begin{array}{l}\mathrm{T}_{7} \\
\mathrm{~T}_{7} \\
\mathrm{~T}_{7} \\
\mathrm{~T}_{7}\end{array}$ & & $\begin{array}{l}\text { Yes } \\
\text { Yes } \\
\text { Yes } \\
\text { Yes }\end{array}$ & & $\begin{array}{l}0.5 \\
0.45 \\
0.45 \\
0.25\end{array}$ & $\begin{array}{l}+4 \\
+2 \\
+3 \\
+3\end{array}$ & $\begin{array}{c}330 \mathrm{~m} . \\
200 \mathrm{~m} . \\
50 \mathrm{~m} . \\
\frac{1}{2} \mathrm{~m} .\end{array}$ & $\begin{array}{l}75 \text { abnormal } \\
9 \text { active } \\
20 \text { fully } \\
\text { IO slightly } \\
5 \text { slightly } \\
\text { IO }\end{array}$ & + & $\begin{array}{l}+ \\
+\end{array}$ & - \\
\hline
\end{tabular}


mechanisms. Cerebral haemorrhages due to exaggerated autonomic hyperreflexia have been reported in the literature following bladder distension and during the last stages of labour in high lesions. We lost one tetraplegic with a complete C6/7 lesion. He had his first prostigmin test on 2.2 .48 when following injections of $0.3 \mathrm{mg}$. the initial blood pressure rose from I20/85 to I 50/90. Apart from vomiting, which was controlled by I/IOo Atropine, there were no undesirable side-effects during three ejaculations. He got married and in I96I he asked for a prostigmin test for the purpose of artificial insemination. This was carried out on 15.9.6I. One and a half hours following injection of the same doses as previously $(0.3 \mathrm{mg}$.) he developed an epileptic fit and died later as a result of a cerebral ventricular haemorrhage. At post-mortem also an undiagnosed abscess behind the pancreas was found.

\section{SUMMARY}

I. The widespread belief that patients with severe injuries of the spinal cord are completely and permanently impotent and infertile is no longer valid.

2. The distinct stimulating effect of intrathecal prostigmin on the sexual organs has opened new possibilities for clinical, physiological and biochemical research in a field where imaginative speculation and deduction on scanty grounds rather than on well-founded evidence have prevailed.

3. A variety of types and degrees of reproductive deficiency can be distinguished by the intrathecal prostigmin test.

4. Future research on the chemistry of the seminal fluid may give clues to abnormalities of the morphology and function of semen.

5. The intrathecal prostigmin test can be utilised for artificial insemination. It is essential that the female partner should undergo a thorough gynaecological and biochemical examination including $\mathrm{pH}$ of vaginal and cervical secretion and assessment of the most suitable time for assisted insemination.

6. Blood pressure and pulse should be examined at regular intervals during the prostigmin test from the start, especially in lesions above $T_{5} / 6$ to counteract excessive autonomic hyperreflexia by appropriate measures (Ansolysen, etc).

7. Patients, especially those with higher lesions should be warned about undesirable side-effects of prostigmin.

\section{RÉSUMÉ}

I. La croyance que les malades avec des lésions sévères de la moëlle épinière en ce qui concerne leur impotence complète et permanente, ainsi que leur manque de fertilité n'est plus maintenant valide.

2. L'effet stimulant sur les organes génitaux de la prostigmine intrathécale a ouvert de nouvelles possibilités de recherches cliniques, physiologiques, et biochimiques, là la spéculation et la déduction sur un terrain fragile plutôt que sur des évidences a prévalu.

3. Les variétés de types, de degrés de déficiences reproductives ont pu être distinguées par le test à la prostigmine.

4. A l'avenir, des recherches sur la biochimie du sperme pourra donner des indications sur la fonction et la morphologie anormale des spermatozoïdes.

5. Les tests à la prostigmine peuvent être utilisés pour l'insémination artificielle. Il est indispensable que la partenaire soit examinée d'une façon gynécologique sérieuse et que le moment le plus favorable pour l'insémination soit relevé.

6. La tension artérielle et le pouls doivent être examinés à des intervalles réguliers pendant le test à la prostigmine depuis le début, surtout en ce qui concerne les lésions au-dessus de D5, D6, de façon à lutter contre une hyper-réflectivité autonome exessive.

7. Les malades, surtout ceux avec des lésions hautes, doivent être avertis des effets secondaires indésirables de la prostigmine. 


\section{ZUSAMMENFASSUNG}

I. Die allgemeine Ansicht, dass Patienten mit schweren Rückenmarksläsionen völlig und dauernd impotent sind, ist nicht mehr haltbar.

2. Der ausgesprochen stimulisierende Effekt von Prostigmin auf die sexuellen Organe hat neue Möglichkeiten für klinische, biochemische und physiologische Untersuchungen in einem Gebiet eröffnet, wo bisher Spekulation und Deduktion an Stelle von klarem Beweis überwogen hat.

3. Verschiedene Typen und Grade sexueller Insuffizienz können durch den subarachnoidalen Prostigmintest ermittelt werden.

4. Zukünflige Untersuchungen der chemischen Zusammensetzung des Semen könnten Aufschluss über seine Morphologie und Funktion geben.

5. Der Prostigmintest kann für artifizielle Insemination verwandt werden. Eine genane gynäkologische Untersuchung einschliesslich Bestimmung des besten Zeitpunkts für die Inseminierung is notwendig.

6. Blutdruck und Puls muss regelmässig während des Prostigmintests gemessen werden, besonders in Läsionen oberhalb $\mathrm{T}_{5}$, um gesteigerte autonomische Hyperreflexie durch geeignete Mittel (Ansolysen) auszuschalten.

7. Patienten, besonders solche mit Zervikalläsionen, sollen über mögliche unerwünschte Seiteffekte unterrichtet werden.

\section{REFERENCES}

Bors, E. (1963). Sexual Function in Patients with Spinal Cord Injury. Proceedings of Symposium, Royal College of Surgeons, Edinburgh. See further literature quoted in this paper.

Bors, E., Engle, E. T., Rosenquist, R.C. \& Holiger V.H. (1950). F. Clin. Endocrinol.10, 38 I. FOERSTER, O. (1936). Handb. d.Neurologie. 5, 193.

GuttmanN, L. (1949). IV Intern. Neurol. Congress, Paris Com. Vol. II, p. 69.

GutTMANN, L. (1953). Treatment and rehabilitation of patients with injuries of the spinal cord. Monograph in Vol. Surgery, Brit. Medical History of World War II, pp. 4225I6. London: H.M. Stationery Office.

GutTMANN, L. (1954). Visceral activity and peripheral circulation in the spinal man. Ciba Foundation Symposium on Peripheral Circulation in Man, pp. I92-203. London: J. and A. Churchill.

GutTMAnN, L. (196I). The sexual problem in spinal paraplegia. Proc. Scientific Meeting, Intern. Stoke Mandeville Games, Rome, 63-69.

GutTMANN, L. \& WhitTeridge, D. (I947). Brain, 70, 36I.

Guttmann, L., Frankel, H. \& Paeslack, V. (1965). F. Paraplegia, 3, I 44.

Horne, H. W., Paul, D. A., \& Munro, D. (1948). New Engl. F. Med. 239, 959.

RIDDOCH, G. (I97I). Brain, 40, 264.

TALBOT, H. S. (I949). F. Urol. 6I, 265.

TALBOT, H. S. (I955.) F. Urol. 3, 9 I.

ThorbuRn, W. (I922). Official History of Great War (Med. Serv.), 200, I I 8.

Zeitlin, A. B. et al (1957). Fertility and Sterility, 337.

\section{SEXUAL FUNCTION AND DYSREFLEXIA}

\section{By A. B. Rossier, W. H. Ziegler, P. W. Duchosal and J. MeYlan ${ }^{1}$}

IN a previous paper (Rossier et al., I969), we have presented the case history of the successful delivery of a tetraplegic patient who showed symptoms of autonomic dysreflexia during labour. There were hypertension and bradycardia but no

${ }^{1}$ Paraplegic Centre (Dr. A. B. Rossier, P.D.) from the University Institute for Physical Medicine and Rehabilitation (Prof. G. H. Fallet), Cantonal Hospital, Geneva, the University Medical Clinic (Prof. A. Labhart, Prof. P. Frick), Cantonal Hospital, Zurich, the Cardiovascular Division (Prof. P. W. Duchosal) and the Infertility Clinic (Dr. J. Meylan), from the University Clinic for Gynecology and Obstetrics (Prof. H. de Watteville), University Cantonal Hospital, Geneva, Switzerland. 